\title{
Inventory of the Most Invasive Alien Plant Species of Latvia in the "Daugavas loki" Nature Park
}

\author{
Santa Rutkovska, Irēna Pučkina, Olga Frolova \\ Daugavpils University, Faculty of Natural Sciences and Mathematics, Department of Chemistry and Geography. \\ Address: Parādes Street 1-310, Daugavpils, LV-5401, Latvia
}

\begin{abstract}
During the realization of the scientific research program for mapping of the most invasive plant species of Latvia in the "Daugavas Loki" nature park (NP) field surveys were carried out during spring, summer and autumn seasons in 2016. In total 100 quadrats were surveyed. Invasive alien plants are species that are non-native to an ecosystem, and may cause a negative effect on environmental quality or human health. The obtained results indicate that the number of invasive alien plants species identified in 2016, i.e. 32 species, considerably increased in comparison with data about the distribution of invasive species given in the nature management plan of the "Daugavas Loki" NP in 2010, when only three species were mentioned. Many invasive plant species have been found in the ruderal biotopes - roadsides in the territory of nature park. The species with the highest number of localities are Acer negundo L., Sambucus racemosa L. and Rumex confertus Willd. The monitoring of certain most invasive species makes it possible to assess the changes in species number and occupied area.
\end{abstract}

Keywords: invasive alien plant species, "Daugavas loki” nature park.

\section{INTRODUCTION}

Alien species are species, which have been introduced to areas outside of their natural range because of direct or indirect human activities [1] - [3].

Neophytes are non-native species introduced in Europe after 1492 [4] and their distribution indicates of human transformed environment. Invasive are considered those neophytes which spreads rapidly in new areas, usually causing significant damage to biodiversity, ecosystem functioning, socio-economic values and/or human health [3]. However, not all neophytes are regarded invasive [5].

Invasive alien species are considered one of the essential component of global climate change [3], [6], leading to habitat homogenization, changes in ecosystem services and contributing to the extinction of certain species [7], [8].

The spread of invasive species depends on the type of habitat [9] and its disturbance regimes. The greater proportion of invasive species is found in heavily disturbed habitats [10]. Invasive species have specific spread patterns: have no natural enemies; is able to occupy a vacant niche and are not affected by local biotic factors in their new habitat [11].

The flora list of Latvia contained 1937 plant species: 1304 were of local origin, 633 were alien species [12]. According to NOBANIS (2014) data, 36 plant species are considered invasive, 12 are potentially invasive and 176 are not considered invasive in Latvia. The information about 192 species has not been established [13]. The main pathways for alien species introduction in Latvia are Baltic Sea coast and river valleys (particularly the Daugava River valley), anthropogenic pathways - roads, railways and seaports [2].

Latvia is bound to implement the Convention on Biological Diversity (1992) and participate in an international project NOBANIS (Nordic-Baltic Network on Invasive Species), the aim of which is to create an electronic database of alien species.

Several studies shown the increase in the number of invasive species in protected areas [14].The spread of alien plants into protected areas is strongly influenced by the presence of trails or roads [15], [16] and by the number of visitors [17], [18].

"The impact of biological invasions can even be worse in protected areas than elsewhere, because these areas preserve key elements of global biodiversity, ensuring the maintenance of essential services for the livelihood of many communities" [8], [19].

In Europe, most protected areas have been influenced by human, including the introduction of alien species and close location to landscapes with little limitations for alien species introduction. Plant invasion in protected areas are significantly related with human activity, density, and native species richness [19], [20]. Protected areas are significant for biodiversity conservation therefore special attention 
should be devoted to the investigation of invasive alien species in these territories.

\section{Study area}

The "Daugavas Loki" nature park (NP) is located in the southeastern part of Latvia in the valley of the Daugava River. Park has been established in 1990 to preserve the unique landscape, biological diversity as well as cultural and historical monuments in the valley of the Daugava River. The territory covers an area of 12562 hectares: forest cover $57.3 \%$, agricultural lands - $36.31 \%$, water bodies - $6.28 \%$, quarries $-0.11 \%$ [21].

In total 1016 vascular plant species listed in the Daugava River valley in the period 1976 - 1983 including 76 adventive species and 68 species, which naturalize [22]. The information contained in the nature management plan (2010) shows that more than 800 vascular plant species (50 specially protected plant species) are recognize in these territory.

The distribution of some invasive species as Acer negundo L., Solidago Canadensis L. s.1., Echinocystis lobata (Michx.) Torr. Et A. Gray etc. is the significant problem in Daugava floodplains [21].

K. Kupffer was one of the first who emphasized the importance of Daugava in species distribution [23] and it is shown that the Daugava River valley function as corridor for invasive plant species distribution [24], [25], [26]. The depopulation process is observed in the territory of NP in the recent years only 8599 inhabitants in 2016) [27]. It should be noted that the population and the economic activity are factors affecting the distribution of invasive species [28]. There are also varieties of roads that may contribute to the spread of invasive species.

\section{MATERIALS AND METHODS}

Fifteen most invasive plant species were inventoried in the "Daugavas loki" NP (Table 1) and Heracleum sosnowskyi Manden. - only one species defined as invasive species in Latvia: Regulations of the Cabinet of Ministers No. 468 "List of Invasive Alien Plant Species" [29]. Other invasive species were recorded during field surveys.

Field research

The distribution of invasive plant species were recorded in the territory of the "Daugavas loki" NP. Inventory of invasive species was done in 2016 (summer - autumn period).

The methodology of Institute of Life Sciences and Technology of Daugavpils University were used (The Project No.7.7/103/2105-P „The development of invasive species monitoring programme").

The territory of the "Daugavas loki" NP was divided into 386 regular grid quadrats of $500 \times 500 \mathrm{~m}$ (25 hectares), but only 100 quadrats were selected for field studies using ArcGIS program „Random selection" tool. Each plot was assigned individual identification numbers. The inventory of invasive species was done using route method. The routes were designed so that each territory was inspected as detailed as possible and the maximum distance between two routes in one quadrate does not exceed $100 \mathrm{~m}$. However, it does not provide complete survey of the territory. Special attention was paid to potential invasion territories of alien plants - roadsides, riverbanks, cemeteries, allotments, degraded territories etc. Quadrats, which geographically coincide with water reservoirs and watercourses, were not surveyed, as well as areas without public access or closed, for example, private property etc. Samples of plants were collected for herbarium.

Latvian classifier of habitats [30] was used for detection of invaded habitats. Nomenclature of vascular plant species was done according to Gavrilova and Šulcs, 1999 [12].

Application of Geographic Information Systems (GPS and GIS)

GPS was used to map the species in the territory of the "Daugavas loki" NP. Field data, obtained with GPS, were converted into a point *.shp file. Further data processing took place in ESRI ArcGIS Geographic Information System software ArcView 10.0. Results were sorted in attribute table in the following order: Species common name, Latin name and biotope. Maps were created using ArcGis program, ArcMap.

Orto-photo maps in 1:10 000 scale, made according to data of areophotographying, done in 2014 by Latvian Geospatial Information Agency were used as the base for vectorization: no. 3422-15, 2443$44,2443-45,2443-54,2443-55,2444-41,2444-42$, 2444-43, 2444-44, 2444-45, 2444-51, 2444-52, 244453, 2444-54, 2444- 55, 3421-14, 3421-15, 3422-11, $3422-12,3422-13,3422-14$.

\section{RESULTS}

Thirty-two invasive alien species in 1224 localities were recorded during the study (Table 1).

Heracleum sosnowskyi Manden.

$H$. sosnowskyi it is considered one of the most invasive plant species in Europe [31] by the impact on ecosystems [32], [33] and human health [32] [35].

H. sosnowskyi is biennial or perennial plant, height is usually 1-3 m, plant seed germination remains for a long time and a single plant can develop more than 3-15 thousand seeds. Ripe seeds easily segregate from plant [32], which contributes to the ease of movement, for example, seeds stick to tires and spread far from the place of origin. Wind and watercourses also play an important role in seed dispersal [31].

$H$. sosnowskyi originates in the central and eastern Caucasus [31] and was first introduced for agricultural purposes into Latvia in 1965 in Madona district, Barkava parish. The first field was sown in 1965 [36]. 
The species is naturalized in the European part of Russia, in Baltic States, Belorussia, Ukraine and Poland [31], [35]. One of the main negative impacts of $H$. sosnowkyi is on native plant communities. The plant forms dense monodominant stands and thus contribute the disappearance of ground-level vegetation species [32], [33]. Therefore, the spread of H. sosnowskyi in protected area may lead to extinction of protected species.

According to the nature management plan of the "Daugavas loki" NP (2010 - 2022), H. sosnowskyi was almost not found in this territory, however, species was found in 15 localities during studies in summer 2016 (Table 1). Large H. sosnowskyi stands were not detected - only one plant/ specimen or small stands were found in 13 localities. Published study results [31], [32], [35] indicate, that this plant is able to spread very rapidly - several tens of kilometers away from the existing plantations. Based on the results obtained during this study, it can be concluded that the species introduction and invasion process started relatively recently in the territory of NP. However, taking into account the fact that all 15 localities were fixed in five quadrats, distribution of $H$. sosnowskyi in the territory of NP is unequal and plant specimens spread close to initial invasion sites. H. sosnowskyi spread analysis in habitat aspect, represent that the most invaded habitats are moderately moist meadows (six localities from 15) and roadsides (five localities).

The fact, that $H$. sosnowskyi successfully spread across roadsides, also are most often mentioned in the scientific literature [31], [32], [37]. Two localities were found in shrubland, one in dry meadow and one in the weedy place. During the study and contrary to other authors [31] localities were not found along the watercourses.

Table I

Invasive alien plant species detected in the "Daugavas loki" nature park.

\begin{tabular}{|c|c|c|c|c|c|c|c|}
\hline No. & Latin name & $\begin{array}{c}\text { Number of } \\
\text { localities }\end{array}$ & $\begin{array}{c}\text { Number of } \\
\text { invaded } \\
\text { quadrats }\end{array}$ & No. & Latin name & $\begin{array}{c}\text { Number of } \\
\text { localities }\end{array}$ & $\begin{array}{c}\text { Number of } \\
\text { invaded } \\
\text { quadrats }\end{array}$ \\
\hline \multicolumn{4}{|c|}{$\begin{array}{l}\text { Invasive plant species (in accordance with Regulation No. 468: List of } \\
\text { Invasive Alien Plant Species) }\end{array}$} & 17. & \multicolumn{3}{|c|}{$\begin{array}{l}\text { Other recorded invasive alien / potentially invasive plant } \\
\text { species }\end{array}$} \\
\hline 1. & Heracleum sosnowskyi Manden. & 15 & 6 & 18. & $\begin{array}{l}\text { Aronia prunifolia (Marshall) } \\
\text { Rehder. }\end{array}$ & 4 & 3 \\
\hline \multicolumn{4}{|c|}{$\begin{array}{l}\text { Monitoring of the priority plant species (in accordance with the contract } \\
\text { No.7.7/103/2105-P data) }\end{array}$} & 19. & Bunias orientalis L. & 17 & 7 \\
\hline 2. & Acer negundo L. & 296 & 52 & 20. & Caragana arborescens Lam. & 17 & 3 \\
\hline 3. & $\begin{array}{l}\text { Amelanchier spicata (Lam.) K. } \\
\text { Koch }\end{array}$ & 55 & 15 & 21. & Caragana frutex (L.)C. Koch & 1 & 1 \\
\hline 4. & Aster $x$ salignus Willd. & 5 & 3 & 22. & Helianthus tuberosus L. & 12 & 4 \\
\hline 5. & Cotoneaster lucidus Schltdl. & 3 & 3 & 23. & Hippophae rhamnoides L. & 1 & 1 \\
\hline 6. & $\begin{array}{l}\text { Echinocystis lobata (Michx.) } \\
\text { Torr. Et A. Gray }\end{array}$ & 31 & 8 & 24. & Malus domestica Borkh. & 84 & 35 \\
\hline 7. & Impatiens glandulifera Royle. & 26 & 10 & 25. & $\begin{array}{l}\text { Parthenocissus quinquefolia } \\
\text { (L.) Planch. }\end{array}$ & 8 & 4 \\
\hline 8. & Impatiens parviflora DC. & 79 & 17 & 26. & Petasites hybridus L. & 6 & 2 \\
\hline 9. & Lupinus polyphyllus Lindl. & 53 & 17 & 27. & Populus alba L. & 7 & 6 \\
\hline 10. & Reynoutria japonica Houtt. & 1 & 1 & 28. & Populus balsamifera $\mathrm{L}$. & 5 & 3 \\
\hline 11. & $\begin{array}{l}\text { Reynoutria sachalinensis (F. } \\
\text { Schmidt) Nakai }\end{array}$ & 4 & 1 & 29. & Rumex confertus Willd. & 167 & 50 \\
\hline 12. & Rosa rugosa Thunb. & 2 & 2 & 30. & Sambucus nigra L. & 19 & 5 \\
\hline 13. & Sambucus racemosa $\mathrm{L}$. & 186 & 45 & 31. & Spiraea chamaedrifolia $\mathrm{L}$. & 1 & 1 \\
\hline 14. & Solidago canadensis L. s.l. & 74 & 23 & 32. & Spiraea $x$ billardii Herincq & 3 & 1 \\
\hline 15. & Solidago gigantea Ait. & 0 & 0 & 33. & $\begin{array}{l}\text { Symphoricarpos albus (L.) } \\
\text { S.F. Blake }\end{array}$ & 1 & 1 \\
\hline 16. & Sorbaria sorbifolia (L.) A. Braun & 3 & 2 & 34. & Syringa vulgaris $\mathrm{L}$. & 36 & 15 \\
\hline
\end{tabular}

Species with priority monitoring status

A. negundo is considered as one of the most invasive plant species in Latvia and the highest number of localities (296) was discovered during field research.

A. negundo is a medium-size tree (about $15 \mathrm{~m}$ in height) with sparse crown from the family Aceraceae. It was introduced into Europe as an ornamental plant and it is considered invasive in Austria, Czech Republic, European part of Russia, Lithuania and Poland [38]. As invasive weed, plant widely spread in degraded habitats and riverbanks in many European countries [38], [39].
The distribution of $A$. negundo in the territory of NP was observed in different biotopes - forests $(23 \%$ of localities, including mixed-wood forests, coniferous forests and black alder stands), meadows $(18 \%)$, shrublands $(11.5 \%)$ and banks of the Daugava River (8\%). Some stands also in quarries, weedy places, below power lines etc. However, this species was observed most often in roadsides $(25 \%)$. The proportion of localities in the Daugava riverbanks and roadsides shows that wind is an important factor contributing the distribution of $A$. negundo in the "Daugavas loki" NP and this fact also has been found by other European researchers [26], [38], [40], [41]. 
However, these results are only partially consistent with the results by Mędrzycki, 2011, where rivers have been mentioned as an important pathway for the introduction of $A$. negundo in several countries. Sikorski and Sikorska, 2016 noted that species reaches a significant level of invasion in riverbanks. The Daugava River is an important factor for plant seed distribution in the territory of NP. It is indicated by stands, located parallel to the river coastline coinciding with the maximum flood level in the river. Stands are large but not dominant, however, $A$. negundo permanent vegetative regrowth can lead to dominance in the flood-plain forests during a period of time [42].

Sambucus racemosa $\mathrm{L}$. is the second most common invasive plant found in the "Daugavas loki" NP in 185 localities in 45 quadrats.

$S$. racemosa is a tall (up to 5 meters) deciduous shrub or small tree from the family Adoxaceae [43]. It was found in the western part of Latvia in the end of 18 century (in 1899) [44], but in the eastern part in 1895 [45]. It was introduced as ornamental plant and it was also used for medicine purposes [46]. The fruits are a bright red and looks especially decorative [43].

Species distributions in different habitats show that plant have broad ecological plasticity and the ability to adapt to various growing conditions [47]. $S$. racemosa was found in meadows, abandoned buildings, weedy places, under power line rotes, in clearcuttings etc.

Although studies shows that $S$. racemosa is not common in forest communities because it is only moderately shade tolerant [48], it was most often found directly in forest and underbrush areas in the territory of NP (49\% of all localities). This once again only proves the invasive features of alien plant species. Roads and roadsides are the second most invaded habitats (38\%) and again, describe it as typical invasive plant species, specific to disturbed biotopes [2], [43]. However, according to the authors, the frequent species occurrence in study area is relatively less associated with human activity - birds and animals distribute plant [43], and S. racemosa is evenly spread throughout the territory.

Other identified invasive alien / potentially invasive plant species

Rumex confertus Willd is a large $(60-150 \mathrm{~cm})$, perennial plant from the Polygonaceae family, which produce a large amount of reproductive seeds [49].

It is an invasive plant in Latvia and its natural range occur south-eastern Europe and western Asia [50]. Plant become established outside it original range due to grain transport (grass seed material from Russia), as well as imported accidentally with the development of transport [2]. It is possible that transportation of soldiers and military equipment (in 1920) contributed to the movement of plant seeds to Latvia. The most rapid spread of $R$. confertus observed in the middle of the 20th century [50], [51]. Plant spreading was recorded in East Asia, around Vladivostok, North Russia, Baltic region, Poland, East Slovakia, the Czech Republic, Austria, Germany, Finland, Norway, Sweden and the United Kingdom [52].

The largest number of localities (167) was found in the territory of "Daugavas loki" NP (Table 1). This species is common throughout the Latvia [51] and was uniformly found in the territory of NP in 50 quadrats.

The research data shows that the distribution of $R$. confertus has little relation with forest areas. It prefers open and sunny places, often forming sparse stands. Such distribution of localities could be explained by the fact that, natural seed dispersal occurs by wind [49], therefore, it requires areas with unrestricted wind flow. It is also approved by the fact that the largest share of $R$. confertus localities in the territory of the "Daugavas loki" NP were found along roadsides - $47 \%$, where vehicles creates specific effects of the wind in addition to the natural wind flow.

$R$. confertus is widely adapted to grow in different moisture conditions - dry meadows, ponds and riverbanks. However, the places more vulnerable to invasion are habitats with sufficient moisture content - moderately moist meadows $(27 \%$ of localities), moist meadows (16\%), shrublands (2\%) and ditch edges $(1 \%)$. These results are also consistent with results from other research studies [2], [26].

Based on the results of other studies [50], [52], distribution of $R$. confertus may cause the essential negative impact on natural territories and protected species, especially in meadows. Native species often get squeezed out and hay quality may deteriorate significantly. In addition, the study results show that in $14 \%$ of localities $R$. confertus are dominant and may form monostands.

\section{Biotopes}

By analysing the distribution of species and habitat types in the territory of the "Daugavas loki" NP, data shows that invasive plants most frequently occur in ruderal biotopes, mainly along roads (found $39 \%$ of all localities. Roads function as corridors for invasive plant species and can contribute the spread of these species inside protected areas [53], [54]. The largest proportion of some invasive plants was found directly along roads. For example, $R$. confertus and Syringa vulgaris L. (47\%), Lupinus polyphyllus Lindl. (68\%), Malus domestica Borkh. (43\%), A. negundo $(35 \%)$ and Impatiens glandulifera Royle. (65\%).

Great proportion of localities were found also in forests and shurblands ( $28 \%$ of the total number), but meadows, mainly moderately moist, represents about $25 \%$ of inventoried localities. Although forests are considered to be relatively stable ecosystems 
however, rapid increase of number of invasive species is observed in forests of Lithuania [55]. $S$. racemosa $(41 \%)$ and Amelanchier spicata (Lam.) K. Koch $(45 \%)$ were the most commonly reported plants in forest in the territory of the NP. A. spicata regarded as one of alien naturalized woody species, widely distributed in the forests of Lithuania [56]. $S$. racemosa is common in many forest communities and it occurs in scattered patches or as individuals [43].

Species most often found in moderately wet meadows is $S$. canadensis (48\%). Usually this species found growing in damp meadows, waterways, and in roadsides along ditches [57].

Such biotopes as fields and gardens, banks of artificial water bodies and regulated watercourse, parks and greeneries each accounted for only one percent of the total number of localities.

\section{IV.CONCLUSIONS}

Only $H$. sosnowskyi is officially recognized as an invasive plant in Latvia. According to nature management plan of the "Daugavas loki" NP, $H$. sosnowskyi was almost not found in this territory in 2010, however, 15 localities were found during research in summer 2016, confirming plant invasive nature.

A. negundo and S. racemosa are considered as most invasive plant species in Latvian and they were found in the largest number of localities.

A. negundo was observed in different biotopes, but most often in roadsides and in the Daugava riverbanks, approving the role of wind and watercourses in the distribution of plant seeds.

In addition, the distribution of $S$. racemosa is related with different habitats and confirms plant adaptation ability to various growing conditions. As $S$. racemosa grows mostly as one specimen, it would be easier to manage this plant, compared with plants producing root sprouts and making stands.

$R$. confertus was most often found from the list of other identified invasive plant species. The distribution of $R$. confertus has little connection with forest areas and plant prefers open and sunny places. $R$. confertus is widely adapted to different soil moisture conditions - dry meadows, ponds and riverbanks.

The survey results show significant changes in the number of invasive species in the territory of NP. Only three invasive plants were mentioned in the nature management plan of the "Daugavas Loki" NP in 2010 and 32 invasive plant species were identified in 2016.

This fact demonstrates ecological flexibility of invasive plant species, their ability to propagate rapidly and to spread in new areas, hence exposing threats for local and protected plant species. The additional risk factor is overgrowing of meadows and pastures in the NP. In such places the changes of existing plant communities occur, thereby developing favourable conditions for invasion by alien species.

Data obtained by implementation of research program of invasive species can help to manage invasive species in the early stages of invasion.

\section{V.ACKNOWLEDGMENTS}

Global Water Partnership in Central and Eastern Europe, Association "Daugavas Savienība" and Daugavpils University supported scientific research programme.

\section{REFERENCES}

[1] P. Pyšek, D. M. Richardson, M. Rejmánek, G. L. Webster, M. Williamson, J. Kirschner, „Alien plants in checklists and floras: towards better communication between taxonomists and ecologists", Taxon, vol. 53, no. 1, pp. 131-143, $2004 \mathrm{~b}$.

[2] A. Priede, „Invazīvie neofìti Latvijas florā: izplatība un dinamika”. Promocijas darbs. Rīga, LU, 2009, 125 lpp.

[3] P. E. Hulme, P. Pyšek, V. Jarošík, J. Pergl, U. Schaffner, M. Vilà, „Bias and error in understanding plant invasion impacts," Trends in Ecology and Evolution, vol. 28, no. 4, pp. 212-218, 2013.

[4] P. Pyšek, Z. Chocholoušková, A. Pyšek, V. Jarošík, M. Chytrý, L. Tichý, „Trends in species diversity and composition of urban vegetation over three decades," Journal of Vegetation Science, , vol. 15, pp. 781-788, 2004a.

[5] P. Pyšek, On the terminology used in plant invasion studies. In: P. Pyšek, K. Prach, M. Rejmánek, M. Wade (eds.). Plant invasions - General aspects and special problems. Amsterdam: Academic Pulblishing, 1995, pp. 71-81.

[6] F. Essl, D. Moser, T. Dirnböck, S. Dullinger, N. Milasowszk,y, M. Winter, W. Rabitsch, „Native, alien, endemic, threatened, and extinct species diversity in European countries," Biological Conservation, vol. 164, pp. 90-97, 2013.

[7] M. A. Schlaepfer, D. F. Sax, J. D. Olden, „The potential conservation value of nonnative species," Conservation Biology, vol. 25, 428-437, 2011.

[8] A. Monaco and P. Genovesi, European guidelines on protected areas and invasive alien species, 2014. Available: https://portals.iucn.org/library/sites/library/files/documents/2 014-070.pdf [Accessed: Feb. 13, 2017].

[9] M. Chytry, L. C. Maskell, J. Pino, P. Pyšek, M. Vilà, X. Font, S. M. Smart, „Habitat invasions by alien plants: A quantitative comparison among Mediterranean:Subcontinental and oceanic regions of Europe," Journal of Applied Ecology, vol. 45, pp. 448-458, 2008.

[10] P. Pyšek, M. Chytry, J. Pergl, J. Sádlo and J. Wild, „Plant invasions in the Czech Republic: Current state, introduction dynamics: Invasive species andinvaded habitats," Preslia, vol. 84, pp. 575-629, 2012.

[11] L. Souza, W. A. Bunn, D. Simberloff, R. M. Lawton, N. J. Sanders, „Biotic and abiotic influences on native and exotic richness relationship across spatial scales: favourable environments for native species are highly invasible," Functional Ecology, vol. 25, no. 5, pp. 1106-1112, 2011.

[12] G̣. Gavrilova and V. Šulcs, Latvijas vaskulāro augu flora. Taksonu saraksts. Rīga: Latvijas Akadēmiskā bibliotēka, 1999, 136 lpp.

[13] NOBANIS (The European Network on Invasive Alien Species). Available: http://www.nobanis.org. [Accessed: Feb. 2, 2017].

[14] P. E. Hulme, P. Pyšek, J. Pergl, V. Jarošík, U. Schaffner and M. Vilà, „Greater focus needed on alien plant impacts in protected areas," Conservation Lettters, vol. 7, pp. 459-466, 2014.

[15] R. Otto, M. A. Arteaga, J. D. Delgado, J. R. Arévalo, C. H. Blandino and J. M. Fernández-Palacios, „Road edge effect and elevation patterns of native and alien plants on an oceanic 
island (Tenerife, Canary Islands)," Folia Geobotanica, vol. 49, pp. 65-82, 2014.

[16] J. R. Arévalo, R. Otto, C. Escudero, S. Fernández-Lugo, M. Arteaga, J. D. Delgado, J. M. Fernández-Palacios, „Do anthropogenic corridors homogenize plant communities at a local scale? A case studied in Tenerife (Canary Islands)," Plant Ecology, vol. 209, pp. 23-35, 2010.

[17] J. A. Allen, C. S. Brown and T. J. Stohlgren, "Non-native plant invasions of United States national parks," Biological Invasions, vol. 11, pp. 2195-2207, 2009.

[18] C. Pickering and A. Mount, "Do tourists disperse weed seed? A global review of unintentional human-mediated terrestrial seed dispersal on clothing, vehicles and horses," Journal of Sustainable Tourism, vol. 18, pp. 239-256, 2010.

[19] L. C. Foxcroft, P. Pyšek, D. M. Richardson, P. Genovesi, Plant invasions in protected areas: patterns problems and challenges, 2013, $661 \mathrm{pp}$

[20] P. Pyšek, P. Genovesi, J. Pergl, A. Monaco, J. Wild, Plant invasions of protected areas in Europe: an old continent facing new problems. In L. C. Foxcroft et al. (eds.), Plant invasions in protected areas: patterns problems and challenges, 2013, pp. 209-240. http://dx.doi.org/10.1007/97894-007-7750-7

[21] Dabas parka "Daugavas loki” dabas aizsardzības plāns, 2010. Available:https://www.daba.gov.lv/upload/File/DAPi_apstipr in/DP_Daugavas_loki-10.pdf [Accessed: Feb. 15, 2017].

[22] И. Фатаре, Флора долины реки Даугавы. Рига, Зинатне, 1989, 168 стр.

[23] K. Kupffer, Grundzüge der Pflanzengeographie des ostbaltischen Gebietes. Rīga: Abhandlungen des HerderInstituts, vol. 1, no. 6, pp. 1-224, 1925.

[24] I. Fatare, Daugavas ielejas flora. Rīga: Zinātne, 1987, 80 lpp.

[25] M. Laiviṇš, Robežsugu horoloǵiskā analīze un veǵetācijas migrācija. Latvijā. Grām.: Latvijas veǵetācija, 18. Rīga: Latvijas Universitātes Bioloǵijas institūts, 2009, 89.-105. 1pp

[26] S. Rutkovska, I. Pučka, I. Novicka, P. Evarts-Bunders, „Relationship of geographic distribution of the most characteristical invasive plant species in habitats adjacent to the river Daugava within the territory of Daugavpils city," Acta Biologica Universitatis Daugavpiliensis, vol. 11, no. 2, pp. 163-175, 2011.

[27] Central Statistical Bureau of Latvia, ,Resident population by sex in cities under state jurisdiction, counties, towns and parishes at the beginning of the year", 2016. Available: http://data.csb.gov.lv/pxweb/en/Sociala/Sociala_ikgad_ied Z__iedzskaits/IS0042.px/?rxid=cd [Accessed: Feb. 20, 2017].

[28] R. Meffin, R. P. Duncan, P. E. Hulme, „Landscape-level persistence and distribution of alien feral crops linked to seed transport," Agriculture, cosystems and Environment, vol. 203, pp. 119-126, 2015.

[29] Regulations of the Cabinet of Ministers No. 468 "List of Invasive Alien Plant Species" (Invazīvo augu sugu saraksts) ("LV", 100 (3884), 02.07.2008.) [stājas spēkā 03.07.2008.]

[30] I. Kabucis, Latvijas Biotopi. Klasifikators. Rīga: Latvijas Dabas Fonds, 2001, 96 lpp.

[31] N. Kabuce and N. Priede, NOBANIS - Invasive Alien Species Fact Sheet - Heracleum sosnowskyi. - From: Online Database of the European Network on Invasive Alien Species - NOBANIS www.nobanis.org, 2010. [Accessed: Feb. 19,2017].

[32] C. Nielsen, H. P. Ravn, W. Nentwig and M. Wade (eds.). The Giant Hogweed Best Practice Manual. Guidelines for the management and control of an invasive weed in Europe. Forest and Landscape Denmark, Hoersholm, 2005, 44 pp.

[33] A. Feher, Biological invasions of plants in Slovakia, Environment and Sustainable development, Rīga, University of Latvia, 2010, pp. 164-165.

[34] O. Jakubowicz, C. Żaba, G. Nowak, S. Jarmuda, R. Żaba, J. T. Marcinkowski, „Heracleum sosnowskyi Manden,” Annals of Agricultural and Environmental Medicine, vol. 16, no. 2, pp. 327-328, 2012.

[35] P. Rzymski, P. Klimaszyk, B. Poniedziałek, „Invasive giant hogweeds in Poland: Risk of burns among forestry workers and plant distribution," BURNS, vol. 41, pp. 1816-1822, 2015.

[36] A. Bērziņš, A. Oḷukalns, D. Lapiṇš, A. Lejiņš, A. Sprincina, G. Gavrilova, V. Liguts, "Latvānis (Heracleum) un tā izplatība Latvijā”, Agronomijas Vēstis, vol. 5, pp. 86-93, 2003.

[37] M. Laiviñš and G. Gavrilova, "Heracleum sosnowskyi in Latvia: sociology, ecology and distribution", Latvijas veǵetācija, 7, Rīga, LU, 2004, 45. - 65. lpp.

[38] P. Mędrzycki, NOBANIS - Invasive Alien Species Fact Sheet - Acer negundo. - From: Online Database of the European Network on Invasive Alien Species - NOBANIS www.nobanis.org, 2011. [Accessed: Feb. 21, 2017].

[39] P. Sikorski and D. Sikorska, ,The role of habitat factors in successful invasion of alien plant Acer negundo in riparian zones”, EGU Gerneral Assembly, vol. 18, 2016. Available: http://meetingorganizer.copernicus.org/EGU2016/EGU201616056.pdf [Accessed: Feb. 16, 2017].

[40] L. Udvardy, Boxelder (Acer negundo). In The most important invasive plants in Hungary (Eds. Botta-Dukát, Z. \& Balogh, L.). Institute of Ecology and Botany, Hungarian Academy of Sciences, Vácrátót, Hungary, 2008, pp. 115-120.

[41] V. Batanjski, B. Bokić, V. H. Širka, M. Radanović, EPPO Prioritisation Process for Acer negundo L. for North Part of Serbia (Vojvodina), EPPO Training, Belgrade 8.-11. July, 2013. Available: http://www.izbis.com/pdf-2013/priorizacijana-izabrane-vrste/Acer\%20negundo\%20L.\%20SERBIA.pdf [Accessed: Feb. 27, 2017].

[42] P. Künstler, "The role of Acer negundo L. in the structure of floodplain forests in the middle course of the Vistula river," Proceedings of the 5th International Conference on the Ecology of the Invasive Alien Plants, October 13-16, 1999, La Maddalena, Sardinia, Italy.

[43] J. L. Fryer, „Sambucus racemosa. In: Fire Effects Information System", 2008 [Online]. U.S. Department of Agriculture, Forest Service, Rocky Mountain Research Station, Fire Sciences Laboratory (Producer). Available: https://www.feis-crs.org/feis/ [Accessed: Feb. 4, 2017].

[44] K. Kupffer. Beitrag zur Kenntnis der Gefasspflanzenflora Kurlands. Korr. B1. d. Naturforscher-Vereins zu Riga, 42, 1899: pp. 100-140.

[45] E. Lehmann, Flora von Polnisch - Livland der Florengebiete Nordwestrusslands, des Ostbalticums, der Gouvernements Pskow und St. Petersburg. Jurjew: Dorpat, 1895, 430 p.

[46] Y. G. Tutin, V. H. Heywood, N. A. Burges, D. M. Moore, D. H. Valentine, S. M. Walters, D. A. Webb, Flora Europaea. Vol. 4. Cambridge University Press, Cambridge, 1976.

[47] USDA NRCS Corvallis Plant Materials Center, 2014. Available: http://plants.usda.gov/java/ [Accessed: Feb. 28, 2017].

[48] J. Kollmann, S. A. Reiner, Light demands of shrub seedlings and their establishment within scrublands. - Flora. 1996, pp. 191-200.

[49] T. Raycheva, „Rumex confertus (Polygonaceae) in the Bulgarian flora," Botanica SERBICA, vol. 35, no. 1, pp. 5559, 2011.

[50] Z. Gudžinskas, M. Kazlauskas, D. Pilāte, M. Balalaikins, M. Pilāts, A. Šaulys, I. Šauliene, L. Šukiene, Lietuvas un Latvijas pierobežas invazīivie organismi. BMK Leidykla, Vilnius, 2014, lpp. 91. - 139.

[51] A. Priede, "Invazīvo svešzemju augu sugu izplatība Latvijā". Grām.: Latvijas veǵetācija, 17. Rīga: Latvijas Universitātes Biologiijas insitūts, 2008, 148 lpp.

[52] V. Jehlík, J. Sádlo, J. Dostálek, V. Jarolímová, L. Klimeš, „Chorology and ecology of Rumex confertus Willd. in the Czech Republic,'Botanica Lithuanica, vol. 7, no. 3, pp. 235244, 2001.

[53] G. Meunier and C. Lavoie, "Roads as Corridors for Invasive Plant Species: New Evidence from Smooth Bedstraw (Galium mollugo)," Invasive Plant Science and Management, vol. 5, no. 1, pp. 92-100, January-March 2012.

[54] P. A. Dar, Z. A. Reshi, M. A. Shahr, „,Roads act as corridors for the spread of alien plant species in the mountainous 
Santa Rutkovska, et al., / Environment. Technology. Resources, (2017), Volume I, 246-252

regions: A case study of Kashmir Valley, India," Tropical Ecology, vol. 56, no. 2, pp. 183-190, 2015.

[55] R. Dobravolskaite, „Development and Age of Amelanchier spicata shrubs,” Acta Biol.Univ. Daugavp., Suppl., vol. 2, pp. $145-152,2010$.
[56] Z. Gudžinskas, Lietuvos flora. Lietuva, Vilnius, vol. 1, pp. 96-103, 2008.

[57] P. L. S. Pavek, Plant guide for Canada goldenrod (Solidago canadensis). USDA-Natural Resources Conservation Service. Pullman, WA, 2011. 